\title{
Journal of the Canadian Historical Association
}

Revue de la Société historique du Canada

\section{Abstracts/Résumés \\ Résumés}

Volume 7, numéro 1, 1996

URI : https://id.erudit.org/iderudit/031111ar

DOI : https://doi.org/10.7202/031111ar

Aller au sommaire du numéro

Éditeur(s)

The Canadian Historical Association/La Société historique du Canada

ISSN

0847-4478 (imprimé)

1712-6274 (numérique)

Découvrir la revue

Citer ce document

(1996). Abstracts/Résumés. Journal of the Canadian Historical Association /

Revue de la Société historique du Canada, 7(1), 277-287.

https://doi.org/10.7202/031111ar

All rights reserved @ The Canadian Historical Association/La Société historique du Canada, 1997

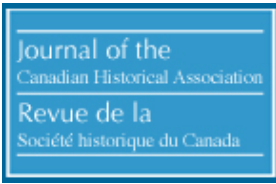




\title{
Abstracts \\ Résumés
}

\section{PRESIDENTIAL ADDRESS \\ DISCOURS DE LA PRÉSIDENTE}

\section{Histoire comparée, histoire plus vraie? Quelques balises et des promesses d'avenir}

\author{
NADIA FAHMY-EID
}

L'auteure jette un regard rétrospectif sur ses propres travaux pour suggérer qu'à ses yeux, la recherche de la vérité constitue toujours le fon dement de la légitimité de la pratique historique. Ce faisant, avec pluseurs auteurs, elle tente de prendre ses distances vis-à-vis des débats entre positivisme et relativisme, qu'elle juge trop étroits. Elle vante les mérites d'une réflexion centrée à la fois sur l'objet de la recherche plutot que sur le chercheur, sur la possibilité, tout limitée et temporaire qu'elle soit, de géréraliser à partir des événements, enfin sur l'exigence de la référence au contexte. Reprenant Marc Bloch et ses héritiers, elle considère l'histoire comparee comme l'une des voies privilégiées d'accès à de telles constructions de théories partielles. En terminant, elle avance que la comparaison est déjà au centre des débats sur le genre en histoire des femmes, mais que pour atteindre son plein potential, cette démarche devrait devenir plus explicite.

The author takes a look back over her own work to suggest that the search for truth is consistently the validating basis for historical inquiry. Like several other authors. she tries to keep her distance from what she perceives as excessively narrow debates over positivism and relativism. She sings the praises of inquiry centred at once on the subject of the research rather than the researcher, on the possibility (however limited or temporary) of generalizing from events and, finally, on the requirement to account for context. Echoing Marc Bloch and his followers, she views comparative history as a special means of achieving such partial theoretical constructions. In closing, she proposes that comparison is already at the centre of debate on gender in women's history, but to reach its full potential, the process should become less abstract. 


\section{"Cool courage should always mark me": John Wilkes and Duelling}

\section{JOHN SAINSBURY}

The duelling activity of John Wilkes, the eighteenth-century English radical, has not received much attention from historians. Yet it tells us a lot about his career and the responses that it evoked from the public at large. Through allegiance to the honour code, Wilkes self-consciously sought to identify with the hegemonic aristocratic culture, an insight which renders problematic his frequent depiction as the champion of a bourgeois style of politics. At the same time, his duelling helped to elicit popular support because it defined a manly persona which could be contrasted with the effeteness of his political enemies, especially those who had allegedly betrayed England's patriotic interests in the country's struggle with France. Significantly, Wilkes's duelling career ended once he found sanctuary in London's civic arena, where the honour code was discounted in favour of demonstrations of political heroism that were not potentially fatal.

Peu d'historiens se sont intéressés aux duels de John Wilkes, ce radical anglais du XVIII siècle. Pourtant, ses duels en disent long sur sa carrière et sur la réaction qu'ils suscitèrent dans le grand public. En restant fidèle au code d'honneur, Wilkes cherchait timidement à s'identifier à la culture aristocratique prépondérante, une constatation qui vient ternir sa réputation de champion de la politique bourgeoise qu'on lui attribuait généralement. Mais par la meme occasion, ses duels lui permettaient d'obtenir la faveur populaire parce qu'ils projetaient de lui une image de virilité qui pouvait contraster avec la veulerie de ses ennemis politiques, surtout ceux qui avaient présumément trahi les intérêts patriotiques de l'Angleterre dans son combal avec la France. Il est significatif que la carriére de duelliste de Wilkes se termine après son entrée dans l'arène politique municipale de Londres, où le code d'honneur cédait le pas aux démonstrations d'héroissme politique, qui n'étaient pas, elles, potentiellement mortelles.

\section{Race Relations in Halifax, Nova Scotia, During the Mid-Victorian Quest for Reform}

\section{DAVID A. SUTHERLAND}

This paper explores the dynamics of race in Nova Scotia's capital city through the 1840s and early 1850s. Black Haligonians actively sought to escape a legacy of marginalisation through participation in the politics of reform, which involved a dual struggle against oligarchy in Nova Scotia and slavery in America. White society 


\section{ABSTRACTS/RÉSUMÉS}

responded with a contradictory blend of accommodation and resistance. Eventually, segregation, rather than integration, prevailed, a result that reflected white prejudice more than black preference.

L'auteur analyse la dynamique raciale dans la capitale de la Nouvelle-Écosse pendant la décennie de 1840 et au début des années 1850. Les Noirs de Halifax ont cherché activement à sortir de leur marginalité en participant aux politiques réformistes, s'attaquant par le fait même à l'oligarchie néo-écossaise et à l'esclavage en Amérique. La société blanche réagit de façon contradictoire en se montrant tantôt inflexible, tantôt prête au compromis. La ségrégation finit par prévaloir sur l'intégration, aboutissement qui correspondait plus aux préjugés des Blancs qu'aux souhaits des Noirs.

\section{A Unifying Vision: Shingwaukonse's Plan for the Future of the Great Lakes Ojibwa}

\section{JANET E. CHUTE}

The speeches of Shingwaukonse between 1846 and 1850 furnish some of the most explicit testimonials to the principle of Native right to be expressed in the United Canadas during the mid-nineteenth century. Shingwaukonse's ideas and actions set precedents which exerted a profound influence on the future course of Indian policy in Canada. By 1850, the chief had defined three major goals for Ojibwa people: first, to establish linkages with government agencies just beginning to exercise jurisdiction in the Upper Great Lakes area; second, to preserve an environment in which Native cultural values and organisational structures could survive; and finally, to devise new strategies conducive to the formation of band governments capable of assuming a degree of proprietorship over resources on Indian lands. Recently a debate has arisen in Canadian historiography over what constitutes "Native agency," as distinct from "Native victimhood." This paper not only rejects the idea that "victimhood" describes the fate of Shingwaukonse's leadership career, but also stresses the need for the concept of "Native agency" to be expanded beyond the semantic parameters set by the agent/victim dichotomy, so that it may prove a better analytical tool to examine historic evidence of this chief's ideas and actions obtained from both oral and documentary sources.

Les discours prononcés par Shingwaukonse entre 1846 et 1850 constituent quelquesuns des témoignages les plus explicites sur le principe du droit autochtone à avoir été entendus au Canada-Uni au milieu du XIX ${ }^{e}$ siècle. Par ses idées et ses actes, Shingwaukonse créa des précédents qui influenceraient profondément l'orientation de la politique indienne au Canada. En 1850, le chef autochtone avait fixé trois objectifs principaux pour le peuple Ojibwa : il s'agissait premièrement d'établir des liens avec 
les organismes gouvernementaux qui commençaient à exercer leur autorité dans la région située au nord des Grands Lacs; deuxièmement, il importait de protéger un environnement qui assurerait la survie des valeurs culturelles et des structures organisationnelles autochtones; troisièmement, il fallait élaborer de nouvelles stratégies menant à la formation de gouvernements de bandes capables d'exercer un certain droit de propriété sur les ressources des terres autochtones. Dans l'historiographie canadienne, on assiste depuis peu à un débat sur le lien à établir entre "agent autochtone "et "victime autochtone. "La présente communication non seulement rejette l'idée que le sort de Shingwaukonse en tant que chef s'explique par le concept de "victime, " mais elle souligne aussi la nécessité d'élargir le concept d' "agent autochtone " audelà des paramètres sémantiques établis par la dichotomie agent/victime, afin qu'ainsi redéfini, ce concept permette un examen plus analytique des idées et des actions de Shingwaukonse qui nous sont rapportées par des sources orales et écrites.

\section{The Origins and Nature of the Holiness Movement Church: A Study in Religious Populism}

\section{LOUISE A. MUSSIO}

This article examines the development of holiness-inspired dissent in Canada by focusing on the Holiness Movement Church, a sect led by Methodist evangelist R.C. Horner and created in opposition to official Methodism in 1895. It investigates the relationship between holiness and Methodism and finds that the Hornerite schism served to discredit the doctrine in the eyes of Methodist leaders. The holiness crisis sheds light on the broad cultural support for the experience, and demonstrates that the pressures placed upon Methodism by dissent were integral to its transformation. The schism reinforced the Holiness Movement's critique of professional elites and the middle class. As such, Hornerism and late nineteenth-century Christian perfectionism can be viewed as part of a broad populist movement intent on defending traditional social values against the forces of modernization.

Le présent article examine le développement au Canada de la dissidence d'inspiration sainte, en se penchant plus particulièrement sur le cas de la Holiness Movement Church, une secte dirigée par l'évangéliste méthodiste R.C. Horner et fondée en 1895 en réaction au méthodisme officiel. L'auteure cherche à comprendre le lien existant entre la sainteté et le méthodisme, et découvre que le schisme hornérite a servi à discréditer la doctrine aux yeux des leaders méthodistes. La crise de la sainteté dévoile l'ampleur de l'appui culturel en faveur de l'expérience et démontre que la pression exercée par la dissidence sur le méthodisme fait partie intégrante de sa transformation. Le schisme a renforcé la critique que le Holiness Movement faisait des élites 
libérales et de la classe moyenne. L'hornérisme et le perfectionnisme chrétien de la fin du XIX $X^{e}$ siècle peuvent de la sorte être considérés comme des manifestations d'un vaste mouvement populiste cherchant à défendre les valeurs sociales traditionnelles contre les forces de la modernisation.

\section{"For Home, Country and Race": The Gendered Ideals of Citizenship in English Elementary and Evening Continuation Schools, 1885-1914}

\section{STEPHEN HEATHORN}

Between 1885 and 1914, English Elementary and Evening Continuation Schools - the institutions designed to cater to the educational needs of the working class - engaged in both formal and informal efforts to indoctrinate their students in the principles of "good citizenship." This ideological initiative was an attempt to construct "appropriate" individual and collective character traits in children, many of whom were never expected to attain formal political rights. The books and lessons of the schools tended to romanticize English history and use specific figures from the past to explain values and traits deemed especially worthy in the "citizen." This article points to the ways in which these projected civic virlues were explained to working-class boys through association with accepted notions of virtuous masculinity. Demonstrated with examples of both real and fictitious martial heroes this masculine code resembled the ethic of service to the nation prevalent in elite educational culture, but with an entirely different result implied.

Entre 1885 et 1914, les écoles du soir élémentaires anglaises - institutions qui avaient été créées pour répondre aux besoins scolaires de la classe ouvrière - s'efforcèrent d'endoctriner officiellement et officieusement leurs élèves et de leur inculquer les principes qui feraient d'eux de "bons citoyens. "Par cette initiative idéologique, on tentait de donner aux enfants des traits de caractère individuel et collectif "adéquats, " même si on savait que nombre de ces enfants n'obtiendraient jamais de véritables droits politiques. Le contenu des livres et les leçons dispensées dans les écoles avaient tendance à romancer l'histoire anglaise et recouraient à des données historiques spécifiques pour présenter les valeurs et les traits de caractère jugés particulièrement dignes d'un "bon citoyen. "Le présent article démontre comment on expliquait aux garçons de la classe ouvrière ces vertus civiques en les associant aux notions acceptées de la masculinité vertueuse. S'appuyant sur des exemples de héros guerriers à la fois réels et fictifs, ce code masculin s'apparentait à l'éthique préconisant le service à la nation, message qui imprégnait la culture scolaire de l'élite, mais qui suggérait des résultats entièrement différents. 


\section{Constructing the Citizen: The Primrose League and the Definition of Citizenship in the Age of Mass Democracy in Britain, 1918-1928}

\section{MATTHEW HENDLEY}

The Primrose League was a patriotic mass organisation nominally independent from, but allied to the British Conservative Party. During the last quarter of the nineteenth century, it politically mobilised large numbers of British women. In addition, through its social activities, the League assisted with the social integration of those holding full political rights with those who did not. The Fourth Reform Act of 1918 fundamentally altered the structure of British politics by tripling the size of the electorate and giving the vote to a significant number of British women for the first time. In this new political environment, Conservatives were concerned with countering the rising Labour Party and limiting the expectations of new voters. After 1918, the Primrose League attempted to define or construct a partisan model of citizenship. The League's model emphasised citizens' duties, individuals' civil rights and the idea of active citizenship. This campaign both helped the Conservative Party to adjust to the new political order and gave the Primrose League a new role to play in the age of mass democracy.

La Primrose League était une organisation populaire patriotique qui, bien qu'indépendante de nom du British Conservative Party, y était associée. Durant le dernier quart du XIX siècle, cette ligue mobilisa politiquement un grand nombre de femmes britanniques. De plus, grâce aux activités sociales qu'elle organisait, la ligue facilita l'intégration sociale de ceux qui détenaient les pleins droits politiques avec ceux qui n'en avaient aucun.

La quatrième Réforme de 1918 modifia fondamentalement la structure politique anglaise en triplant le nombre d'électeurs et en donnant pour la première fois le droit de vote à un nombre considérable de femmes britanniques. Dans ce nouvel environnement politique. les Conservateurs cherchèrent à bloquer la montée du Parti travailliste et à diminuer les attentes des nouveaux électeurs. Après 1918, la Primrose League tenta de définir ou d'établir un modèle partisan de citoyenneté. Le modèle préconisé par la ligue valorisait les responsabilités des citoyens, les droits individuels et l'idée d'une citoyenneté engagée. Cette campagne permit au Parti conservateur de s'ajuster au nouvel ordre politique et à la Primrose League de jouer un rôle renouvelé à une époque de démocratie populaire. 


\title{
The Masculine Mountie: The Royal Canadian Mounted Police as a Male Institution, 1914-1939
}

\author{
STEVE HEWITT
}

1914 to 1939 was a very important period in the history of the Royal Canadian Mounted Police (RCMP). The Force found its very existence threatened. It also was transformed as it lost and then regained a role at the provincial level of policing, found itself amalgamated with the Dominion Police in 1920, and experienced widely fluctuating personnel levels throughout the period. Finally, it took on a security/intelligence role that would last until 1984. "The Masculine Mountie" looks at the Mounted Police in this era. Specifically the paper uses gender and ethnic analysis to explore the values and characteristics of the RCMP and how they affected the work it performed. Who Mounties were leads directly into what they did. These two aspects are very related, a reality that is too often ignored in much of the writing about Canada's national police force. Finally, the paper connects these various threads in an effort to deal with the important question of why the RCMP survived and prospered in its era of great uncertainty.

La période de 1914 à 1939 fut déterminante dans l'histoire de la Gendarmerie royale du Canada (GRC) dont l'existence même fut alors remise en question. La GRC subit des transformations diverses : elle perdit et regagna son rôle de police provinciale, elle fusionna avec la Police fédérale en 1920 et eut à son service un personnel aux compétences fort variées. Finalement, on lui confia en plus les services de renseignement et de sécurité, responsabilités qu'elle gardera jusqu'en 1984. "The Masculine Mountie" étudie donc la GRC pendant cette époque de transition. L'auteur utilise plus précisément une grille d'analyse sexuelle et ethnique pour cerner les valeurs et les caractéristiques de la GRC et pour comprendre comment celles-ci influaient sur son travail. Se demander qui étaient les gendarmes amène nécessairement à s'interroger sur ce qu'ils faisaient. Ces deux aspects sont intimement reliés, toutefois ils ont été peu abordés dans les ouvrages portant sur la force constabulaire nationale du Canada. L'auteur tente donc ici de renouer tous les liens qui permettraient de savoir pourquoi la GRC a survécu à cette période de grande incertitude et pourquoi elle s'est même fortifiée. 


\section{Mobilizing Canada: The National Resources Mobilization Act, the Department of National Defence, and Compulsory Military Service in Canada, 1940-1945}

\section{DANIEL BYERS}

Compulsory military service took on the most organized, long-term form it has ever had in Canada during the Second World War. But few historians look beyond the politics of conscription to study the creation, administration or impact of a training system that affected more than 150,000 people. Faced with the Mackenzie King government's policy of conscripting manpower only for home defence, and their own need for overseas volunteers, Army leaders used conscripts raised under the National Resources Mobilization Act to meet both purposes. This paper explores the Army's role in creating and administering the compulsory military training system during the war, the pressures put on conscripts to volunteer for overseas service, and the increased resistance to volunteering that resulted by 1944. The consequences of the Army's management of conscription came very much to shape the political events that took place in 1944, and cannot be fully understood outside that context.

C'est pendant la Deuxième Guerre mondiale que la conscription obligatoire prend la forme la plus organisée et la plus longue que le Canada ait connue. Cependant, la plupart des historiens sont restés cantonnés dans l'étude des politiques relatives à la conscription et peu d'entre eux se sont intéressés à la création, à l'administration et à l'impact du programme d'entraînement qui a touché plus de 150000 personnes. Liés par la politique du gouvernement de Mackenzie King, qui ne permettait la conscription que pour la défense du territoire canadien, et poussés par leurs propres besoins de volontaires pour le service outre-mer, les commandants de l'armée durent donc utiliser à ces deux fins les conscrits de la Loi sur la mobilisation des ressources nationales. Le présent article étudie le rôle que l'armée a joué dans la formation et la gestion du programme d'entraînement militaire obligatoire pendant la guerre, les pressions exercées sur les conscrits afin qu'ils se portent volontaires pour le service outre-mer et l'opposition accrue au volontariat qui en résulta en 1944. La façon dont l'armée administra la conscription eut des conséquences certaines sur le déroulement des événements politiques de 1944, qui ne peuvent être complètement compris hors de ce contexte. 


\title{
The Mobilisation of Native Canadians During the Second World War
}

\author{
MICHAEL D. STEVENSON
}

Historians have paid scant attention to the compulsory conscription of men under the National Resources Mobilisation Act (NRMA) in Canada during the Second World War. This paper uses the mobilisation of Native Canadians as a case-study to determine the depth and extent of human resource mobilisation policies between 1940 and 1945. Government mobilisation departments and agencies relied on a remarkably decentralised and permissive administrative structure to carry out the NRMA mobilisation mandate. These organizational traits were exacerbated by active Native Canadian opposition to conscription and other factors, such as the geographic isolation and poor health of many Native men. As a result, a patchwork of disparate, inconsistent and ineffectual mobilisation policies affecting Canadian Indians was adopted during the course of the war.

Les historiens se sont peu intéressés à la conscription obligatoire édictée par la Loi sur la mobilisation des ressources nationales au Canada pendant la Deuxième Guerre mondiale. Dans le présent article, l'auteur prend comme étude de cas la mobilisation des Autochtones canadiens pour mesurer la profondeur et l'ampleur des politiques de mobilisation des ressources humaines entre 1940 et 1945. Les ministères et les organismes gouvernementaux chargés d'appliquer la Loi sur la mobilisation reposaient sur une structure administrative décentralisée et permissive pour remplir leur mandat. Ces caractéristiques organisationnelles étaient accentuées par l'opposition active des Autochtones à la conscription et par d'autres facteurs, comme l'isolement géographique et la mauvaise santé de beaucoup d'hommes autochtones. En conséquence, pendant toute la durée de la guerre, les politiques de mobilisation concernant les Autochtones furent disparates, inconsistantes et inefficaces. 


\title{
"Let us heed the voice of youth": Laundry Detergents, Phosphates and the Emergence of the Environmental Movement in Ontario
}

\author{
JENNIFER READ
}

This paper uses the 1960s detergent debate to examine the shift to environmental attitudes in Ontario. The first phase of the detergent issue began in 1963 and addressed excessive foaming in the province's water created by detergent residues. The Ontario Water Resources Commission ignored protest from municipal governments and allowed the manufacturers to resolve the problem on their own. In 1969, the environmental phase of the issue began when phosphate-based detergents were blamed for the dwindling quality of Great Lakes water. The appearance of strong advocacy groups, especially Pollution Probe from the University of Toronto, marked this stage. Pollution Probe used science and strong media relations to mobilise public support to ban phosphate-based detergents. The paper assesses the success of strategies employed during both phases of the debate and ties that to the emergence of environmental attitudes among the public.

L'auteure part du débat des années 1960 sur les détersifs pour examiner les changements d'attitude face à l'environnement en Ontario. La première phase de la controverse sur les détergents commença en 1963 et porta sur la présence excessive dans les eaux de la province d'écume produite par les résidus détersifs. La Ontario Water Resources Commission ignora les protestations des gouvernements municipaux et demanda aux manufacturiers de résoudre eux-mêmes le problème. L'année 1969 marqua le début de la phase environnementale, alors que l'on rendait les détergents à base de phosphate responsables de la détérioration de la qualité de l'eau des Grands Lacs. Pendant cette phase apparurent des groupes de défense environnementaux solidement organisés, comme le Pollution Probe de l'Université de Toronto. Ce groupe utilisa les découvertes scientifiques et ses puissantes relations avec les médias pour mobiliser l'opinion publique contre l'utilisation de détergents à base de phosphate. Le présent article mesure le succès des stratégies employées pendant les deux phases du débat environnemental et relie le tout à l'émergence d'une conscience écologique dans la population. 


\section{“Mrs. Chatelaine” vs. "Mrs. Slob": Contestants, Correspon- dents and the Chatelaine Community in Action, 1961-1969}

\section{VALERIE J. KORINEK}

Scholars and critics alike have presumed that readers of popular women's magazines were merely passive consumers. That was not the case with Chatelaine magazine. Reader commentary was regularly featured in the magazine and often influenced editorial decisions. This analysis of the Mrs. Chatelaine contest provides a demographic profile of the reading community, an overview of the text and the producers, an examination of the national community of readers created at Chatelaine; it also explores the reaction of "average readers" to products of popular culture. In summary, readers' responded in a host of ways to the periodical. Some enjoyed the preferred meanings offered by the magazine, particularly of traditional fare (like the contest) which celebrated paragons of feminine virtue. Other readers were resistant to this material - they criticised, challenged, or parodied the contest - clearly demonstrating that "average" readers did not passively accept material which was at odds with their lives.

Chercheurs et critiques ont toujours tenu pour acquis que les lectrices des magazines féminins populaires étaient des consommatrices purement passives. Ce constat ne s'applique pas à la revue Chatelaine, qui publiait régulièrement les commentaires de ses lectrices, commentaires qui influençaient souvent les décisions éditoriales. La présente analyse du concours "Mrs. Chatelaine " fournit un profil démographique de la clientèle des lectrices, une vue d'ensemble des textes et des producteurs, et un examen de la communauté nationale des lectrices créée par Chatelaine; on y étudie aussi la réaction de la "lectrice moyenne" aux produits de la culture populaire. En résumé, les lectrices réagissaient de mille et une façons au contenu de la revue. Certaines appréciaient les idées véhiculées par le magazine, particulièrement celles à saveur traditionnelle (comme le concours) qui célébraient les parangons de vertu féminine. D'autres se montraient récalcitrantes à de telles orientations: elles critiquaient, contestaient ou parodiaient le concours, démontrant ainsi clairement que les lectrices "moyennes" ne gobaient pas passivement un contenu qui ne correspondait pas à leur vie. 